\title{
Individual Innovation Competence: A Systematic Review and Future Research Agenda
}

\author{
Laura-Maija Hero $^{1}$, Eila Lindfors ${ }^{1} \&$ Vesa Taatila ${ }^{1}$ \\ ${ }^{1}$ University of Turku, Finland \\ Correspondence: Laura-Maija Hero, University of Turku, Finland
}

Received: September 20, 2017

Accepted: October 5, 2017

Online Published: October 16, 2017

doi:10.5430/ijhe.v6n5p103

URL: https://doi.org/10.5430/ijhe.v6n5p103

\begin{abstract}
Learning for innovation is a central element in European policymaking in developing higher education. Students often learn in project settings together with work organizations developing new solutions, products and services. These authentic creative, social and collaborative settings offer an attractive learning environment. The aim of this study was to determine the factors involved in individual innovation competence to be able to design, tutor and assess the pedagogical processes where authentic open-ended tasks are being solved transforming novel ideas into usable products or services. After defining the extraction criteria using a limited sample of articles, a bias-assessed systematic review was conducted of empirical research articles published in 2006-2015. Twenty-eight journal articles were ultimately included in the review. Despite the volume of academic literature in this field, comparatively few studies providing findings addressing the review objectives could be found. There was, however a reasonable weight of research evidence to support the result. The findings suggest that personal characteristics, such as flexibility, achievement orientation, motivation and engagement, self-esteem and self-management, future orientation, creative thinking skills, social skills, project management skills, and content knowledge and making skills can be needed in collaborative innovation process. These findings have implications for pedagogical innovation processes and for competency-based assessment.
\end{abstract}

Keywords: Individual innovation competence, Systematic review, Pedagogical innovation process, Collaborative learning, Innovation pedagogy, Higher education, Project-based learning

\section{Introduction and Background}

Innovation is required to benefit business, solve difficult problems faced by society and to ease everyday life. European Commission has recognized an innovation gap: higher education institutions are not contributing as much as they should to innovation in the wider economy. The performance varies strongly between EU regions. (European commission 2017) Learning for innovation is thus a central element in European policymaking in developing education (European Commission, 2012, 2013; OECD, 2004, 2008; Tether, Mina, Consoli, \& Gagliardi, 2005; Toner, 2011). High expectations is being placed on the cooperation and networking between individual people, employees, entrepreneurs and even students as sources of innovation (Høyrup, Bonnafous-Boucher, Hasse, Lotz, \& Moller, 2012; Kesting \& Ulhøi, 2010; Hasu, Honkaniemi, Saari, Mattelmäki, \& Koponen, 2014; Miettinen, 2013; Hippel, 2005). Young people are expected to be prepared to collaborate in solving future problems and producing innovations in areas that presently do not exist (Sawyer, 2006, 2012, 2014; Zang, Hong, Scardamalia, Teo, \& Morley, 2011). It is the task of education to equip people with suitable competences. The aim of this study was to determine, based on a systematic review, what these competencies could be for the purposes of planning and organizing education and to find avenues for further research to promote learning for innovation. Without understanding these competencies it is difficult to facilitate pedagogical innovation processes offering a platform for this type of competence development (Lepistö \& Lindfors, 2015).

In higher education praxis, the controversial concept of innovation as an outcome of students' work is often regarded as an economical term that is not usable in educational context. If we look closer to the definitions, we notice that it is quite usable in project-based learning when describing projects outcomes such as novel products or services that are not only ideas, but solutions taken into use. Amabile (1996) defined innovation as the successful implementation of creative ideas. According to Sawyer (2006), innovation is an outcome of an innovation process whereby collaboratively created ideas are transformed into a single product or other end result, often through interactions with several stakeholders; the process involves rapid prototyping and testing, manufacturing (making), and implementing 
the product or service (see also Baregheh, Rowley, \& Sambrook, 2009). Innovations are not only technical novelties. Innovations can be any kind of novel products, processes, services or other types of outcomes, but not only ideas or inventions. In this study, an innovation is a novelty made concrete and implemented to convey value. In educational contexts, it is often unnecessary to strive primarily for radical innovations (Schumpeter, 1942; Veryzer, 1998) to produce learning as learning happens during the journey. The authentic innovation project as a learning process can resemble incremental innovation processes. E.g. in higher education contexts students nowadays often learn in innovative project settings together within a network of industry or other work organizations in authentic creative, social and collaborative settings to transform novel ideas into usable solutions to solve problems. (e.g. Rautkorpi \& Hero) These types of authentic innovation processes are often naturally or systematically organised as cross-disciplinary teamwork (Edmondson, 2013; Farrell, 2001). Also in the contexts of basic education students should be able to produce multiple creative solutions to open-ended tasks to develop their competence and innovativeness in changing circumstances (e.g., Bencze, 2010; Cropley \& Cropley, 2010; McLellan \& Nicholl, 2011). These solutions are also often implemented in practice by providing them into use to bring value in students' surrounding world (Lepistö \& Lindfors, 2015). To conclude, a pedagogical innovation process is an authentic innovation process whereby collaboratively created ideas are transformed into a concrete end result, made concrete, prototyped and tested, and implemented to convey value in the surrounding world through interactions with several stakeholders (following Sawyer 2006).

Although innovation processes benefit from collaboration (John-Steiner, 2000; Sawyer, 2003), new knowledge in real-life networks can begin with an individual (Nonaka \& Takeuchi, 1995). In these pedagogical innovation processes students are often judged on how well they perform based on some form of individualised assessment (Sawyer, 2014). However, it is unclear what kind of competencies could develop in these authentic innovation processes.

The general term competence needs clarification in this context. Competence is the integration and manifestation of knowledge, skills and attitudes in performance in a specific, pre-defined context and in concrete, authentic tasks (following Mulder, 2012; Mulder \& Gulikers, 2011; Sturing, Biemans, Mulder, \& De Bruijn, 2011). The competencies needed in innovation processes can refer to knowledge, skills and attitudes (Zhuang, Williamson, \& Carter, 1999), but the influence of individual characteristics also seems to be significant (Da Silva \& Davis, 2011). Based on these preconditions, individual innovation competence is understood here as a synonym for a set of personal characteristics, knowledge, skills (or abilities) and attitudes that are connected to creating concretised and implemented novelties via collaboration in complex innovation processes. Similar to other competences, innovation competence can be learned and developed (Bruton, 2011; Peschl et al., 2014).

Individual perspective to innovation is found to be underrepresented in research (Peschl et al., 2014; Standing et al., 2016). This systematic review aims to contribute to this research gap by seeking answers to the question: What are the factors of individual innovation competence and possible avenues for future research? This information is likely important for curriculum design and teachers at different educational levels in setting aims and objectives, as well as planning pedagogical processes and individualised assessment.

Many literature reviews have come close to the definitions and research topic of this study. Iddris (2016) sought to understand how firms develop their innovation capability to achieve competitive advantage along several dimensions: knowledge management, organisational culture, organisational learning, leadership, collaboration, creativity, idea management and innovation strategy. Mention (2012) identified how intellectual capital affects the innovation process, outcomes and performance of companies or firms, but they did not specify competence-related factors of an individual. Smith, Courvisanos, Tuck and McEachern (2011) examined company learning and development systems through human resource management. These studies investigated innovation capability at the firm or network level, not as individual competence. A study by Timmermans, Van Linge, Van Petegem, Van Rompaey and Denekens (2012) explored the factors that contribute to or hinder team learning in the innovation process, while Standing et al. (2016) focused on the role and actions of individuals in an innovation process setup, not on competence. Thurlings and Evers' (2015) study is most similar to the present one. Still, their aim was to unveil teachers' innovative behaviour and competence was narrowly understood as skill and knowledge. When considering these review studies, there was no bias-assessed systematic review that would present a more holistic picture of innovation competence.

\section{Research Design}

\subsection{Systematic Review and Research Question}

This systematic review aimed to contribute to the identified research gap by seeking answers to the question: What are the factors of individual innovation competence based on recent empirical research? The aim was to create an 
overview of the individual innovation competence usable in educational settings to promote innovation learning. The secondary aim was to find avenues for future research in this important area of cross-disciplinary research. Thus, a systematic review of 2006-2015 published research articles in peer-reviewed, academic journals was conducted using an explicit method to identify, select and critically appraise relevant research data (see Greenhalgh, 1997; Higgins, 2008; Petticrew \& Roberts, 2006). A preliminary search of the term individual innovation competence yielded no results. However, the concept innovation competence seemed to be used with several meanings. The search criteria and terms were brainstormed among all three authors. The following search terms were used: innovation competenc*, innovativeness, innovation capability/ies, competence to innovate, innovation ability/ies and innovation skill/s. Synonyms were employed because the term individual innovation competence is not an established concept. The Boolean search string TI innovation competence OR TI innovativeness OR TI innovation capabilit* OR TI competence to innovate OR TI innovation abilit* OR TI innovation skill* was applied.

The systematic identification of studies was limited to databases based on their relevance to the field of education. The chosen databases were EBSCO (including ERIC, CINAHL and nine others), PsychINFO (including ProQuest/Education and Psychology) and Scopus. The search was limited to 10 years (2006-2015) to yield a reasonable, still adequate sample of peer-reviewed studies.

\subsection{Inclusion and Exclusion Criteria}

The inclusion and exclusion criteria were first set by thematising a limited sample of the data. Material from the EBSCO databases (limiters peer-reviewed, only 5 years, 2009-2014) was used as a sample $(N=524)$ to determine the extraction criteria. The initial inclusion criteria was includes definition of innovation competence or its defined synonyms. When categorising the resulting articles, we found six larger categories of approaches and contexts for the concept of innovation competence and its synonyms. Most of the articles examined the innovation competence of organisations (e.g., Kodama \& Shibata, 2014; Wang, 2014), country-, region- or area-level innovation capabilities or competences (e.g., Chen et al., 2009; DiPietro, 2009) or the innovativeness of non-human things, such as innovative software (e.g., Lim, Moriarty, \& Huthwaite, 2011). Consumer innovativeness was used in the context of the diffusion or adoption of novel products or technological goods. In the context of marketing, communication or consumer studies, individual-level innovativeness was defined e.g. as the ability to adopt, try, buy or accept innovations, and it was then defined as a person's ability to understand, receive, socially estimate, spread, implement and use innovations (e.g., Goswami \& Chandra, 2013; Manning, Bearden, \& Madden, 1995), but not create them. Extraction criteria were thus defined as concerning: 1. Organisations (organisation, industry, firm and product programmes); 2. Geographical areas (such as country and region); 3. Non-human entity innovation competence (i.e., animal, product, policy, fashion and marketing); 4. Innovation competence defined as technological device or other new thing adoption (diffusion or adoption of innovation); 5. Publication was not a peer-reviewed academic research journal. 6 . Not empirical research. The discipline, or field of research, was not used as exclusion criteria since innovation concerns many disciplines and paradigms. The inclusion criteria were redefined as 1 . Includes the definition of innovation and innovation competence or a synonym defined in this study; 2. Concerns individual human beings; and 3. Empirically tests factors of innovation competence. 


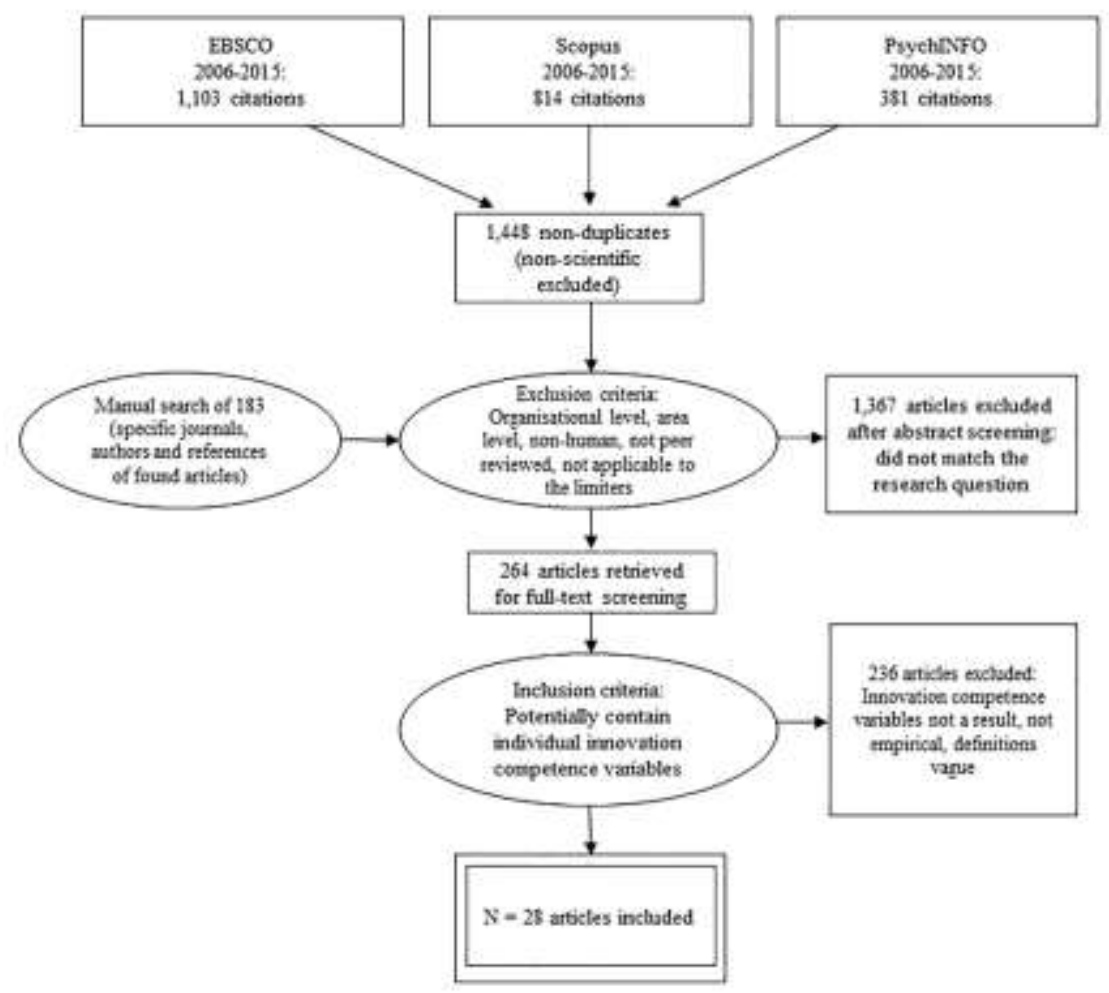

Figure 1. Data extraction path (following Moher, Liberati, Tetzlaff, Altman, \& The PRISMA Group, 2009).

1,448 non-duplicate research articles were found that matched the search criteria (Figure 1). A manual search in specific innovation-related journals yielded 183 articles; thus, 1,631 articles were subjected to an abstract screening against the extraction criteria. Articles that met the exclusion criteria were extracted. The full text of 264 articles was reviewed. Of these, 236 were still excluded based on poor quality, vague definitions or poor match to the research question. The authors of two articles were contacted for more information on their research design (Avvisati, Jacotin, \& Vincent-Lancrin, 2013; Chell \& Athayde, 2011).

\subsection{Final Material and Analysis}

The final sample consisted of 28 articles that matched the inclusion criteria. Key information from the selected articles was defined, including the article title and year, context, study design, study population, subjects and overall risk-of-bias assessment. (Appendix 1.)

The included studies represent the studied phenomenon. Ten of the studies were conducted in an educational context (higher education, secondary or comprehensive education), while 14 occurred in an organisational context (organisational psychology, human resource management or business studies); four studies occurred in both contexts (educational and organisational). Six of the studies were qualitative, 19 were quantitative, and three used mixed methods. Nine of the studies were case studies, two of which were multiple case studies. The study design and research methods varied considerably.

The final research data were subject to a three-author bias assessment to make the quality of the material as transparent as possible. A cross-analysis by the three authors was used to avoid possible reviewer subjectivity bias. Each article was individually assessed, considering the following: the methodological rigor in identifying potential flaws; the generalisability of the study; the strengths and weaknesses caused by research design, conduct, analysis and interpretation of findings; and the validity, reliability, method and sample. The criterion for moderate bias was a narrow cultural sample (e.g., research was conducted in one country only), which had adequate numbers of informants and well-reported analyses. A study had medium bias if there was an inadequate sampling of the research subjects, a poorly described analytical method or a scope that was too narrow or small to draw conclusions. A study was considered highly biased if it included several of the aforementioned criteria and the study was inadequately reported. The inclusion criteria for the assessment was set to "medium risk of bias". 
The analysis was conducted using a data-driven content analysis of the research literature gathered for the systematic review (following Krippendorff, 2004). The sampling of the chosen material was done by organising the data, evaluating the definition of innovation and extracting the competency factors. Coding was completed by one author and then, separately as blind review, by the two other authors to limit subjectivity. After several discussions, inter-reviewer agreement reached $100 \%$. The semantic analysis was aimed at exploring the meaning that was derived from the relationships among the concepts in the text (Cohen, Manion, \& Morrison, 2007). After coding, the thematization of the subclass and the main classes was conducted by two authors and discussed until agreement was reached.

Finally, the thematization was cross-validated by all three authors against the competence factors of the studies assessed to contain no risk of bias. The studies with no risk of bias included the large-scale quantitative studies in an educational context in which the minimum requirement was < 200 informants (Avvisati et al., 2013; Lindfors \& Hilmola, 2015; Vila, Pérez, \& Morillas, 2012) and in an organisational context in which the minimum requirement was < 200 informants (Bjornali \& Støren, 2012; Keller, 2012; Montani, Odoardi, \& Battistelli, 2014; Vila et al., 2014; Waychal et al., 2011) as well as the qualitative studies with no risk of bias (Chatenier, Verstegen, Biemans, Mulder \& Omta, 2010; Chell \& Athayde, 2011; Nielsen, 2015).

\section{Results}

When considering the relevance of the articles and their empirical results, the definitions for innovation varied, but were well in line with each other. In most of the articles, innovation was clearly differentiated from creativity. According to Bruton (2011), a creative product is understood as a novel solution to a problem; once it has been applied to a valuable practical application, it becomes an innovation. According to Mathisen, Martinsen and Einarsen (2008), creativity refers to the development of novel and useful ideas and innovations towards the application of ideas. The majority of the articles defined innovation based on outcome. Some of the articles defined innovation according to the process. Edwards-Schachter, García-Granero, Sánchez-Barrioluengo, Quesada-Pineda and Amara (2015), Jaiswal and Dhar (2015) and Waychal, Mohanty and Verma (2011) followed Amabile (1996) in defining innovation as the successful implementation of creative ideas with a subsequent economic and/or social value generation in the market and/or society. According to Vila, Pérez and Coll-Serrano (2014), innovation was the process of applying novel ideas and new knowledge to increase the efficiency in the production of goods and services. Bjornali and Støren (2012) and Waychal et al. (2011) defined innovation as a process of turning opportunity into new ideas and putting them into widely used practice. The common factors in these definitions are the creative and novel ideas and the obligation to implement them for the benefit of society or the market. In summary, the definitions of the research articles supported the precondition of the systematic review process.

\subsection{Individual Innovation Competence: Upper And Sub-categories}

On the basis of the included articles, some of the factors were supported in the original studies related to innovation competence, while other factors did not seem to be predictors of innovation development. Factors in the original studies that were determined to be irrelevant or to score low as factors of innovation competence were excluded. After the factors were identified, a data-driven thematization was conducted. 
Table 1 . The classification of individual innovation competency factors

\begin{tabular}{|c|c|c|}
\hline Upper category & Sub category & Competency factors \\
\hline \multirow{5}{*}{$\begin{array}{l}\text { Personal } \\
\text { characteristics }\end{array}$} & Flexibility & Flexibility $(4,6,17,18,20,28)$; Sense of humour $(10)$ \\
\hline & Motivation and engagement & Motivation $(6,8,10,17,18,19,28)$; Engagement $(7,8,19,28)$ \\
\hline & Achievement orientation & $\begin{array}{l}\text { Ambition }(6,18) \text {; Takes initiative }(10,23) \text {; Goal orientation and } \\
\text { generation }(10,19,20) \text {; Learning goal orientation (19); Achievement } \\
\text { and value orientation }(28)\end{array}$ \\
\hline & Self-esteem & Self-esteem $(2,6,16,23)$ \\
\hline & Self-management & $\begin{array}{l}\text { Self-management }(3,7,5,8,13,24) \text {; Self-efficacy and control }(8,5,7 \text {, } \\
\text { 16); Ability to focus on tasks (28); Persistence and conscientiousness } \\
(2,23) \text {; Ability to perform well under pressure (3) }\end{array}$ \\
\hline \multirow[t]{2}{*}{ Future orientation } & Future thinking & Future orientation and creative visioning (19); Visioning $(19,22,28)$ \\
\hline & $\begin{array}{l}\text { Alertness to new } \\
\text { opportunities }\end{array}$ & $\begin{array}{l}\text { Alertness to new opportunities }(3,23,25,26) \text {; Openness to } \\
\text { experiences }(5,6) \text {; Curiosity }(7,6,9) \text {; Proactiveness (6); Ability to cope } \\
\text { with non-routine tasks and un-certainties }(7,16) \text {; Risk-taking ability } \\
(20,23) \text {; Moderate resistance to change }(5,11)\end{array}$ \\
\hline \multirow[t]{2}{*}{$\begin{array}{l}\text { Creative thinking } \\
\text { skills }\end{array}$} & Creativity skills & $\begin{array}{l}\text { Creativity }(2,3,4,6,7,8,9,11,10,17,18,19,20,21,28) \text {; Imagination } \\
(2,18) \text {; Inventiveness }(7,14) \text {; Ability to generate new ideas and } \\
\text { solutions }(1,3,4,9,18,19,20,25,26,28) ; \text { Ability to do things } \\
\text { differently }(16) \text {; Problem-solving skills }(9,10,11,12,17,27)\end{array}$ \\
\hline & Cognitive skills & $\begin{array}{l}\text { Learning skills }(7,9,14,27) \text {; Ability to rapidly acquire }(3) \text {, exchange } \\
\text { and combine }(27) \text { knowledge; Cognitive skills }(2,3,7,9) \text {; Analytical } \\
\text { thinking }(3,9,12,17) \text {; Skills in thinking }(2,17) \text {; Ability to combine } \\
\text { and interpret }(7) \text {; Willingness to question your own and others' ideas } \\
(3,26)\end{array}$ \\
\hline \multirow[t]{3}{*}{ Social skills } & Collaboration skills & $\begin{array}{l}\text { Co-operation skills }(2,3,9,15,17,20,24,27) \text {; Teamwork skills }(4,9 \text {, } \\
\text { 12); Social astuteness and sensitivity ( } 7,24) \text {; Interpersonal } \\
\text { management }(7,24) \text {; Interpersonal influence }(7,23) \text {; Championing } \\
\text { (3); Ability to motivate others }(5,20) \text {; Ability to build trust ( } 7) \text {; Ability } \\
\text { to mobilise the capacities of others }(3,25,26)\end{array}$ \\
\hline & Networking skills & $\begin{array}{l}\text { Ability to create partnerships (7); Internal and external networking } \\
(2,9,12,15,23,28)\end{array}$ \\
\hline & Communication skills & $\begin{array}{l}\text { Communication }(2,3,7,21) \text {; Ability to make your meaning clear to } \\
\text { others ( } 7 \text { ); Presentation skills }(3,12,17,24,25) \text {; Ability to write } \\
\text { reports, memos or documents (3); Ability to write and speak in a } \\
\text { foreign language (3); Negotiation skills }(3,7,9) \text {; Active listening ( } \\
\text { 24); Brokering (information exchange) }(3,23)\end{array}$ \\
\hline \multirow[t]{2}{*}{$\begin{array}{l}\text { Project management } \\
\text { skills }\end{array}$} & Process management skills & $\begin{array}{l}\text { Ability to manage collaborative knowledge creation process }(7,20) \text {; } \\
\text { Project management skills }(7,9,20) \text {; Planning skills (19); Ability to } \\
\text { use time efficiently (3); Research and development skills (1) }\end{array}$ \\
\hline & Management skills & Decision-making skills $(27,28)$; Leadership skills (8) \\
\hline \multirow[t]{3}{*}{$\begin{array}{l}\text { Content knowledge } \\
\text { and making skills }\end{array}$} & Content knowledge & $\begin{array}{l}\text { Mastery of one's own field or discipline }(2,3,12,15) \text {; Knowledge of } \\
\text { other fields or disciplines }(3,9)\end{array}$ \\
\hline & Making skills & $\begin{array}{l}\text { Designing skills (4); Prototyping skills (4); Skills in making } \\
\text { (know-how) }(2,17) \text {; Esthetical and psychomotor skills (17) }\end{array}$ \\
\hline & Technical skills & $\begin{array}{l}\text { Technical skills }(1,12,17) \text {; Ability to use computers and the internet } \\
(3,25)\end{array}$ \\
\hline
\end{tabular}

As shown in table 1, 71 competency factors were organised into 17 sub-categories and further to 6 upper categories, which were named as coherently as possible. The upper categories were identified as personal characteristics, future orientation, creative thinking skills, social skills, project management skills, and content knowledge and making skills. 


\subsubsection{Personal Characteristics}

Personal characteristics that explain innovation competence were found in most of the research articles (Table $1, N=$ 16) and were thus chosen as the first upper category. According to Chatenier et al. (2010), personal characteristics were defined as the underlying traits that comprise an individual's personality and influence his or her innovation behaviour. Personal characteristics are common across various situations and endure for a reasonably long period. It was not easy to distinguish a personal characteristic from a skill or attitude, as they clearly overlap (Avvisati et al., 2013; Celik, 2013). For example, risk-taking versus control in a non-routine task (Keller, 2012) indicates that different abilities are needed at different phases of the innovation process. In total, 16 personal characteristic factors were thematised to this upper category. These competency factors were themed and divided into five sub-categories.

Flexibility is defined as a stretch mindset (Waychal et al., 2011) and can be parsed as a willingness to shift the approach and to scrutinise ideas. According to August-Brady (2000), flexibility is the integrative, evolving and resilient response to recognised change and uncertainty. It is based on openness and willingness to change, which results in a greater diversity of choice, effectiveness and efficiency in outcomes.

Motivation and engagement is defined as finding the internal motivation and willingness to solve a problem or perform a task (Waychal et al., 2011). Motivation implies a strong emphasis on goals, achievement and value orientation (Montani et al., 2014; Waychal et al., 2011). A high level of motivation may promote a climate in which high-quality solutions are searched for, developed and promoted, leading to innovative results. Motivation is the need for achievement, autonomy, persistence and goal orientation (Mathisen et al., 2008). Engagement, as the willingness to accomplish the aim of the process (Waychal et al., 2011), could also belong to the achievement orientation sub-category, but it was paired with motivation following Chell and Athayde's (2011) classification. According to Montani et al. (2014), both intrinsic motivation and learning goal orientation are essential to creative idea generation although the latter may potentially have a greater motivational power for boosting individual engagement in both the early and late stages of an innovative activity.

Achievement orientation is defined as ambition, the ability to take initiative, goal orientation and generation, learning goal orientation and achievement, and value orientation. According to Mathisen et al. (2008), a high level of ambition may promote innovative results. The ability to take initiative is defined as seeking an opportunity and is applied to a person who does things before being asked or compelled (Santandreu-Mascarell, Garzon, \& Knorr, 2013). Montani et al. (2014) defined goal orientation as the attitude towards gaining results or proactive target generation propensity, which is a self-regulatory mechanism involving two distinct goal-directed processes: envisioning (i.e., setting future change-oriented goals) and planning (i.e., defining a roadmap for action to achieve the desired outcomes). Montani et al. (2014) studied learning goal orientation within innovation processes and defined it as an emphasis on understanding or mastering new aspects, desiring change-oriented goals and preferring challenging and risky situations that offer new opportunities. Change-oriented goals, which tend to be naturally associated with challenging and uncertain ventures such as innovation, are of particular value to persons with a strong learning goal orientation.

Good self-esteem characterises people with innovation competence and is defined as a concept that represents a person's perceived value or self-worth (Avvisati et al., 2013; Keller, 2012). Self-esteem affects performance, behaviour and attitudes at work because it influences self-perceptions of confidence, worthiness, competence and capabilities. Santandreu-Mascarell et al. (2013) emphasise the importance of independence and self-confidence, which both indicate the ambition for autonomy from rules or control by others. According to Cerinšek and Dolinšek (2009), the development of innovation is associated with significant risk and uncertainty. It is hard to predict the progress and results of innovation processes, which can influence self-confidence and motivation.

Self-management is defined as a competency in several articles (Bjornali \& Støren, 2012; Celik, 2013; Chatenier et al., 2010; Chell \& Athayde, 2011). Self-management and self-efficacy appear to be synonyms and are defined as the belief in one's ability to organise and execute a course of action required to manage prospective situations (Celik, 2013). In this review, self-efficacy is the sense of control that one has towards internal or external factors in a given situation.

\subsubsection{Future Orientation}

Future orientation as an innovation competency factor is highlighted in 12 studies. According to Chatenier et al. (2010), a future-oriented person picks up on signals, recognises changes and creates a vision. Future orientation was also mentioned in the creativity category (Montani et al., 2014). In this review, it was separated as an important skillset in its own right because it was mentioned in many of the articles. Future orientation includes two 
sub-categories: future thinking and alertness to new opportunities. Based on this review, it is essential to watch for future opportunities and take advantage of them when creating novelties. The sub-category of visioning is synonymous with envisioning, which was defined by Montani et al. (2014) as the ability to set change-oriented goals and as a pre-decisional phase. The importance of intuition for innovation and personal proactiveness was highlighted by Chatenier et al. (2010) as future orientation. The more non-routine a problem is, the more future orientation may be needed to provide an original or creative solution (Keller, 2012). Future orientation is defined in this research as the ability to foresee and anticipate, to make plans for and to organise future possibilities (see Nurmi, 1991, 2005; Seginer, 2009).

Alertness to new opportunities is the ability to cope with non-routine tasks and uncertainties; it involves an ability to take risks and offers a moderate resistance to change. This sub-category is important as innovation offers a non-routine task environment. Openness to experiences and curiosity are defined as the willingness to confront new situations and the flexibility to experience them (Celik, 2013; Waychal et al., 2011). Proactiveness is the ability to develop new ideas and take initiative (Cerinšek \& Dolinšek, 2009). Coping with chaos and uncertainty reflects an ability to deal with unexpected situations, the flexibility to deal with plans and deadlines and the ability to improvise (Chatenier et al., 2010). As the innovation process is aimed towards an unknowable future, it is important to have moderate resistance to change during the process. If the need for clarity is moderate, the ability to deal with ambiguous and complex tasks is important (Keller, 2012).

\subsubsection{Creative Thinking Skills}

Creative thinking skills are defined in this review as creative competences and cognitive skills. Creativity is a key innovation competency factor in most studies. According to Cerinšek and Dolinšek (2009), creativity is the ability to generate new ideas independent of their possible practicability and future value. The main measure of creativity is originality. According to Edwards-Schachter et al. (2015), the concept of creativity as a transferable competency comprises individual characteristics, such as creative personality; thought processes; personal traits and thinking styles; creative processes, such as problem-solving skills; and actions towards developing creative products within the contexts in which creativity occurs, including the social context and collective learning environments. Creativity also involves the ability to adopt views from different perspectives and to envision new possibilities based on open observations of an environment. Idea generation, imagination and problem-solving skills are seen as core abilities of an innovative person. Inventiveness is defined as the ability to seek novelties, take risks and experiment while remaining pragmatic and sensitive to the environment and market (Chatenier et al., 2010). Based on the sample of this study, creativity cannot be solely defined as generating imaginative, original and novel ideas since it plays a significant role in problem-solving activities to evaluate and assess knowledge and skills to reach a novel and practical solution (Lindfors \& Hilmola, 2015). Problem solving is defined as a generic skill that is key to innovation and synonymous with the creative process (Edwards-Schachter et al., 2015; Jack, Anderson, \& Connolly, 2014).

Cognitive skills are also considered crucial for innovation. According to Treffinger, Young, Selby and Shepardson (2002), cognitive skills refer to convergent or critical thinking and are defined in the data as analytical thinking skills (Bjornali \& Støren, 2012; Cobo, 2013; Jack et al., 2014; Lindfors \& Hilmola, 2015), general thinking skills (Avvisati et al., 2013; Lindfors \& Hilmola, 2015), the willingness to question ideas (Bjornali \& Støren, 2012; Vila et al., 2012) and the ability to acquire and interpret new knowledge (Chatenier et al., 2010). Learning skills are defined as the ability to rapidly acquire knowledge (Bjornali \& Støren, 2012) and to exchange and combine knowledge (Wang \& Shuai, 2013).

\subsubsection{Social Skills}

Social skills are the core competency in innovation development in most of the included research articles. Social skills are necessary for interaction and communication with others (see McFall, 1982; Riggio, 1986); social skills are essential for innovation processes. Social skills are divided into three sub-categories: collaboration, networking and communication skills. Collaboration skills were mentioned as core skills for innovation in 18 studies. Teamwork skills allow otherwise dispersed local knowledge to be combined, which allows innovative capabilities to be improved (Wang and Shuai, 2013). In most of the articles, collaboration skills were defined as the ability to work productively with others (Bjornali \& Støren, 2012) or in teams (Bruton, 2011; Cobo, 2013; Jack et al., 2014). Social astuteness is defined as a person's ability to understand social situations and interpersonal interactions, and to remain sensitive to the motivations and responsibilities of different parties (Tsai, Chen, \& Chin, 2010). It involves expressing empathy and playing a political game (Chatenier et al., 2010). Interpersonal management is defined as the skill to appropriately adapt one's behaviour to each situation to elicit particular responses and social control (Tsai et al., 2010). Influencing skills, the ability to phrase personal perceptions and feelings in a diplomatic way (Chatenier et 
al., 2010) and the ability to motivate and mobilise the skills of other people are considered crucial interpersonal management skills (Bjornali \& Støren, 2012; Celik, 2013; Nielsen, 2015; Vila et al., 2012, 2014).

Networking skills refer to the ability to develop, maintain and use networks effectively to forge beneficial alliances and coalitions that are critical to innovation (Avvisati et al., 2013; Chatenier et al., 2010). Communication skills are well supported in the research articles; the most supported communication skills are presentation skills (Bjornali \& Støren, 2012; Jack et al., 2014; Lindfors \& Hilmola, 2015; Tsai et al., 2010; Vila et al., 2014). Brokering skills are defined as information exchange skills in which participating people link information and knowledge from various internal and external sources, which leads to new opportunities (Bjornali \& Støren, 2012). Negotiation and active listening are necessary in team and network interactions with other people. (Table 2)

\subsubsection{Project Management Skills}

In the analysed research articles, seven competency factors were classified as project management skills. Project management skills were defined as the ability to establish specific, challenging and accepted team goals; to diagnose and formulate learning objectives; to coordinate and synchronise activities, information and tasks among team members; to design a strategic plan; to carry out the proposition systematically and sequentially; to feel responsible for the team; to identify human, material and experiential resources for accomplishing various kinds of learning objectives; to organise complementarities; and to monitor, evaluate and provide feedback on overall team and individual performance (Chatenier et al., 2010; Cobo, 2013; Nielsen, 2015). Project management skills were divided into process management skills and general management skills.

Process management skills are needed in the collaborative knowledge-creation process (Chatenier et al., 2010; Nielsen, 2015) to plan (Montani et al., 2014), manage (Chatenier et al., 2010; Chell \& Athayde, 2011; Nielsen, 2015), make decisions (Wang \& Shuai, 2013; Waychal et al., 2011) and efficiently research and develop (Arvanitis \& Stucki, 2012) in innovation processes. Management skills are decision-making skills (Wang \& Shuai, 2013; Waychal et al., 2011) and leadership skills (Chell \& Athayde, 2011) used in innovation processes or projects.

\subsubsection{Content Knowledge and Making Skills}

The sixth category in individual innovation competence is content knowledge and making skills. These competences are related to individuals' knowledge and skills in their field of expertise as well as in other fields.

Content knowledge is defined as substance knowledge, or the knowledge of a discipline or professional field. Content knowledge is mentioned as an innovation competency factor in only five studies (Avvisati et al., 2013; Bjornali \& Støren, 2012; Jack et al., 2014; Kasule, Wesselink, Noroozi, \& Mulder, 2015; Lindfors \& Hilmola, 2015). Avvisati et al. (2013) used the term subject knowledge, which is understood as a synonym for content knowledge. They defined subject knowledge as knowledge about a content-specific field or discipline; in other words, subject knowledge was specialization to the branch (Jack et al., 2014). Knowledge of other fields or disciplines seem to be required in the innovation process as well (Bjornali \& Støren, 2012; Cobo, 2013).

Making skills is the 'know-how' and practical solution design which is emphasised in educational research. The making phase in the innovation process occurs when abstract ideas are concretised into practical solutions (Avvisati et al., 2013; Bruton, 2011; Lindfors \& Hilmola, 2015). According to Lindfors and Hilmola (2015), innovation learning includes the process of designing, planning and making as well as the practical solution. Usability is a key element in creating and making an innovation or a solution that is novel, functional and usable in practice. Technical, aesthetic and psychomotor skills are needed to produce a prototype and to concretise the solution in practice (Arvanitis \& Stucki, 2012; Avvisati et al., 2013; Bruton, 2011; Jack et al., 2014; Lindfors \& Hilmola, 2015). (Table 2)

\subsection{Comparison with non-biased Studies}

The research articles included in the data comprised a heterogeneous collection of qualitative and quantitative studies that were executed in a variety of educational and organisational contexts. (See appendix 1.) They differed from each other in terms of research strategies, methods, sample sizes and contexts. The analytical comparison was executed by determining whether the sub-classes of competences found in this review received support from non-biased research articles. All thematised upper categories were supported by the non-biased quantitative and qualitative research articles of the systematic review. The non-biased quantitative research executed in educational (Avvisati et al., 2013; Lindfors \& Hilmola, 2015; Vila, Pérez, \& Morillas, 2012) and organisational (Bjornali \& Støren, 2012; Keller, 2012; Montani, Odoardi, \& Battistelli, 2014; Vila et al., 2014; Waychal et al., 2011) contexts supported the sub-categories formed in this individual innovation competence analysis. Sub-categories in the competency category of social skills and future thinking skills were found in all non-biased research articles. The personal characteristics category was 
supported in the related categories of flexibility, motivation and engagement, and self-esteem by all research articles. However, there were three exceptions out of the seventeen sub-categories: achievement orientation, process management skills and future orientation were not supported by the research conducted in the educational contexts. Yet, achievement orientation and project management skills were supported by qualitative research. The sub-category of management skills was supported only by qualitative studies, and the sub-category of future thinking was supported only by quantitative studies executed in organisational contexts. The content knowledge, making skills and technical skills categories were supported by non-biased quantitative research (Chatenier, Verstegen, Biemans, Mulder \& Omta, 2010; Chell \& Athayde, 2011; Nielsen, 2015) but not by qualitative research. The most questionable competency category seems to be project management skills, which were not acknowledged at all in educational settings.

\section{Discussion}

This study contributes to the educational aim to prepare students to collaborate in solving future problems and producing innovations in areas that presently do not exist (Sawyer, 2006, 2012, 2014; Zang, Hong, Scardamalia, Teo, \& Morley, 2011). By understanding competency outcomes, innovation processes can be harnessed in educational purposes to foster learning. The learning process can be organised to address competency gaps in relation to the desired problem solving and future oriented, innovative solution. Regarding the innovation process as a learning platform, successful competency development during the process is the core target.

It was surprising how few articles could be included in the final analysis. However, we used strict inclusion and bias assessment criteria to meet the preliminary innovation competence definition. Although many peer-reviewed academic research articles were found on innovation competence and its synonyms, most articles covered competences unrelated to individual perspective in developing innovations, such as consumers who adopt (rather than develop) new technical innovations (e.g. Goswami \& Chandra, 2013) or organisation's innovation competence as the development resource capacity of a firm (e.g., Kodama \& Shibata, 2014). There was, however a reasonable weight of research evidence to support the findings.

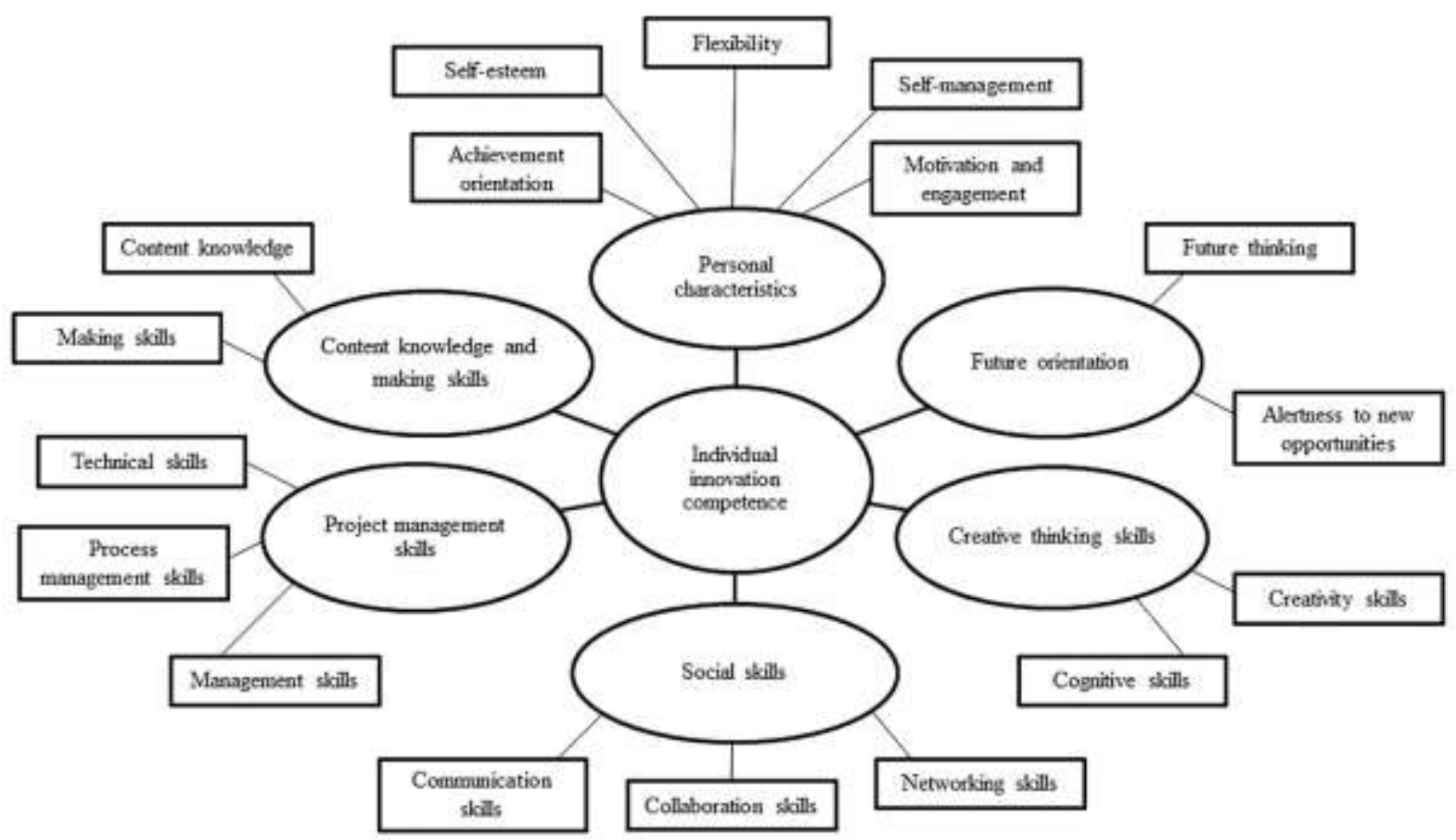

Figure 2. Individual innovation competence categories for future testing in educational contexts

Although the context, sample and research strategy vary, the results were not contradictory but parallel. 71 competency factors were divided into 17 sub-categories, which comprise 6 upper categories that form the main classification. Based on the findings, it seems that individual innovation competence is a combination of certain personal characteristics, future orientation, creative thinking skills, social skills, project management skills, and content knowledge and making skills (Figure 2). 
Based on this review, in the collaborative activity of innovation processes a successful participant should have good self-esteem and achievement orientation, be flexible, motivated and engaged with the task at hand. Future orientation is needed to remain alert to new experiences and opportunities for innovation. Creative thinking skills help in idea generation and problem solving, while cognitive skills help acquire, exchange and combine new knowledge in the form of analytical thinking. The ability to combine and interpret information as well as the willingness to question ideas are included among creative thinking skills. Social skills form the largest competency category in individual innovation competence. According to the analysis, personal communication skills are needed to make one's intentions clear to others. Networking skills are important in creating partnerships and building relationships. Interpersonal communication and management skills are needed for productive cooperation. As part of individual innovation competence, project management skills are important for finishing the innovation process through the efficient use of time and decision making. Content knowledge about one's field or other fields as well as making skills in the form of designing, prototyping, making and using technical equipment comprise the sixth competency category of innovation competence. The most surprising factor seems to be however, that knowledge of other fields than one's own content knowledge or discipline is required in the innovation process (Bjornali \& Støren, 2012; Cobo, 2013).

Considering the definitions of innovation proposed by Amabile (1996) and Sawyer (2006) and the competences found in the review, it is possible to draw several conclusions. Innovation, defined as a novelty made concrete and implemented to bring value, requires new and creative ideas that can be produced and implemented in practice to reach an outcome. It is possible to argue that creative thinking skills and future orientation support the requirement of novelty in the outcome. It is also possible to argue that the requirement that the innovation be concrete is supported by making skills (designing, prototyping). The requirement of real-world implementation is supported by social skills (collaboration, networking and communication skills) and project management skills. As innovation processes are often naturally or systematically organised as cross-disciplinary teamwork (Edmondson, 2013; Farrell, 2001; John-Steiner, 2000; Sawyer, 2003, 2014), the personal characteristics of participants are arguably crucial. The findings of this review support this view. Flexibility, motivation and engagement, achievement orientation, self-esteem and self-management potentially support successful teamwork and the innovation process.

According to Edwards-Schachter et al. (2015), creativity, innovation and entrepreneurship should be integrated as generic or transferable 'meta competences' rather than as independent competences. When comparing the findings with reviewed articles, this view is not supported. This review promotes a coherent understanding of individual innovation competence on its own right. The findings in the included studies have some categories that are similar to the cathegorization of this study. Thurlings and Evers (2015) highlighted individual factors that influence innovative behaviour, such as personality (openness and curiosity), traits (attitudes and beliefs, motivation, learning goal orientation, self-efficacy, persistence, humour and job satisfaction) and competence (recognising and evaluating opportunities, problem solving and content knowledge of teaching).

\section{Conclusions}

The findings from this review have implications for teachers, curriculum designers, researchers and policymakers at all levels of education, from basic to higher education. Regarding the innovation process as a learning environment, successful competency development during the process is the core target. According to Spencer and Spencer (1993), competence always includes an intent, which is the motive or trait that causes action towards an outcome. Innovation could be considered an intent for the development of a competence. As a goal-directed learning environment, the innovation process should enable the development of personal characteristics, future orientation and creative thinking skills, social skills, project management skills and content knowledge and making skills. The learning environment should be organised to support future visioning, facilitate idea generation, and foster the creation of new solutions to authentic problems. It should also allow social interaction in the form of team projects to incorporate project management activities. Moreover, the learning environment should allow for the design of useful solutions and an introduction to other relevant disciplines. Multidisciplinary team formation could allow multiple perspectives, skill variety and new knowledge interfaces while introducing also to other disciplines. Individual innovation competence could serve as the basis for presenting relevant curricula, programmes, learning tasks and tutoring when educating and fostering learning through innovation processes for innovation.

However, there are several limitations that should be carefully considered before applying this research. The first limitation is that the material was limited. Though we used a systematic approach to select academic articles for review, other researchers may identify additional articles. However, this view is arguably true of any systematic literature review (Greenhalgh, Robert, Macfarlane, Bate, \& Kyriakidou, 2004). As the material consisted only of 
peer-reviewed, academic articles found in the EBSCO, Scopus and PsychINFO databases, data are missing from this review. The lack of academic books, scholarly theses and other research could have potential implications on the results. A waekness is that, although a number of competency factors were identified, there was no uniform view of competence that predicted innovation. The concept definitions of innovation varied although the bias assessment was strict. Still, congruent factors were found in the definitions and these were well in line with the definition set for this review. Another potential limitation lies in the method used for the sample selection; this method focused solely on individual perspective despite the likelihood that the surrounding organisational, team level factors and cultural settings would have strong effects on innovation. For example, this can be detected by the importance of the social interaction competences of individuals. Another potential limitation arises from the heterogeneity of the sample. The analysed articles varied greatly by context, sample size and type as well as by research strategy. The sample consisted of both qualitative case studies and the quantitative analysis of large samples collected using different methods in a variety of cultures. Furthermore, some articles were considered to be biased by the authors. However, while heterogeneity may have created some uncertainties in the analysis, the selected articles were not contradictory in terms of the presented results. The rigorous selection and extraction process ensured that, each study was conducted with adequate scientific credibility within its own research genre. Thus, the heterogeneity of the sample can actually be considered a strength of this study because the results are supported by numerous methods collected in different cultural settings. There was a reasonable weight of research evidence to support the suggested findings to give direction to pedagogical processes.

The findings indicate that despite the multitude of different approaches to innovation competence, further research is recommended. We have identified five areas in which further research could be conducted. First, the large competence entity (Table 2) should be further investigated because it is not clear if it pertains only to innovation process as defined in this study. Second, further research should be pursued to test the findings in different phases of the innovation process within organisations (see Vila et al., 2014), but also in educational contexts. E.g. project management skills, (which were not acknowledged at all in studies conducted in educational settings) should be studied in educational facilities in the context of authentic, project-based learning of different age cohorts through pedagogical innovation processes (Lepistö \& Lindfors, 2015; Rautkorpi \& Hero, 2017). Third, methods for assessing competence development is recommended to be developed and tested. Different types of self-, peer and teacher assessment methods could be designed to help the students understand competence gaps and opportunities for learning in projects. In team learning contexts making individual innovation competence transparent and understood to all members can have positive impact on team success. Our fourth recommendation for further research is that the findings should be compared with entrepreneurial competences (e.g. Jena \& Sahoo, 2014; Mitchelmore \& Rowley, 2010, 2013; Taatila, 2010) after testing in educational settings. While studies have recognised the connection between entrepreneurship and innovation (Becherer \& Maurer, 1999; Bergh et al., 2011; Bunk, 1994; Szerb, 2003), we found that innovation and entrepreneurship were also linked (Bjornali \& Støren, 2012; Cerinšek \& Dolinšek, 2009; Chell \& Athayde, 2011; Edwards-Schachter et al., 2015; Gundry, Ofstein, \& Kickul, 2014; Kasule et al., 2015; Santandreu-Mascarell et al., 2013; Waychal et al., 2011). The fifth area for further research is the different competences in each phase of the innovation process (Standing et al., 2016). For instance, different competences are potentially needed in the project management phase than in the preliminary future-oriented and creative phases. Innovation processes are potentially excellent learning platforms in different educational contexts if the developed competences can be validated to define innovation outcomes. Further research on individual innovation competences is recommended to guarantee relevant assessment criteria, curricula, programmes, learning tasks and tutoring for education which utilises innovation processes to foster individual innovation competence as human capital.

\section{Declaration of Interest}

This research did not receive any specific grant from funding agencies in the public, commercial or not-for-profit sectors.

\section{References}

References marked with an asterisk (*) indicate the eligible articles included in the analysis of this research.

Amabile, T. M. (1996). Creativity in context: Update to the social psychology of creativity. Boulder, CO: Westview Press.

*(1) Arvanitis, S., \& Stucki, T. (2012). What determines the innovation capability of firm founders? Industrial and Corporate Change, 21(4), 1049-1084. https://doi.org/10.1093/icc/dts003 
August-Brady, M. (2000). Flexibility: A concept analysis. Nursing Forum, 35(1), 5-13. https://doi.org/10.1111/j.1744-6198.2000.tb01171.x

*(2) Avvisati, F., Jacotin, G., \& Vincent-Lancrin, S. (2013). Educating higher education students for innovative economies: What international data tells us. Tuning Journal for Higher Education, 1(1), 223-240. https://doi.org/10.18543/tjhe-1(1)-2013pp223-240

Baregheh, A., Rowley, J., \& Sambrook, S. (2009). Towards a multidisciplinary definition of innovation. Management Decision, 47(8), 1323-1339. https://doi.org/10.1108/00251740910984578

Becherer, R. C., \& Maurer, J. G. (1999). The proactive personality disposition and entrepreneurial behaviour among small company presidents. Journal of Small Business Management, 37(1), 28-36.

Bencze, J. (2010). Promoting student-led science and technology projects in elementary teacher education entry into core pedagogical practices through technological design. International Journal of Technology and Design Education, 20(1), 43-62. https://doi.org/10.1007/s10798-008-9063-7

Bergh, P., Thorgren, S., \& Wincent, J. (2011). Entrepreneurs learning together: The importance of building trust for learning and exploiting business opportunities. International Entrepreneurship and Management Journal, 7(1), 17-37. https://doi.org/10.1007/s11365-009-0120-9

*(3) Bjornali, E. S., \& Støren, L. A. (2012). Examining competence factors that encourage innovative behaviour by European higher education graduate professionals. Journal of Small Business and Enterprise Development, 19(3), 402-423. https://doi.org/10.1108/14626001211250135

*(4) Bruton, D. (2011). Learning creativity and design for innovation. International Journal of Technology and Design Education, 21(3), 321-333. https://doi.org/10.1007/s10798-010-9122-8

Bunk, G. P. (1994). Teaching competence in initial and continuing vocational training in the Federal Republic of Germany. European Journal of Vocational Training, 1, 8-14.

*(5) Celik, K. (2013). The relationship between individual innovativeness and self-efficacy levels of student teachers. International Journal of Scientific Research in Education, 6(1), 56-67.

*(6) Cerinšek, G., \& Dolinšek, S. (2009). Identifying employees' innovation competency in organisations. International Journal of Innovation and Learning, 6(2), 164-177. https://doi.org/10.1504/IJIL.2009.022811

*(7) Chatenier, E. D., Verstegen, J. M., Biemans, H. A., Mulder, M., \& Omta, O. F. (2010). Identification of competencies for professionals in open innovation teams. $R \& D$ Management, 40(3), 271-280. https://doi.org/10.1111/j.1467-9310.2010.00590.x

*(8) Chell, E., \& Athayde, R. (2011). Planning for uncertainty: Soft skills, hard skills and innovation. Reflective Practice, 12(5), 615-628. https://doi.org/10.1080/14623943.2011.601561

Chen, Y., Yang, Z., Shu, F., Hu, Z., Meyer, M., \& Bhattacharya, S. (2009). A patent based evaluation of technological innovation capability in eight economic regions in PR china. World Patent Information, 31(2), 104-110. https://doi.org/10.1016/j.wpi.2008.06.010

*(9) Cobo, C. (2013). Mechanisms to identify and study the demand for innovation skills in world-renowned organisations. On the Horizon, 21(2), 96-106. https://doi.org/10.1108/10748121311322996

Cohen, L., Manion, L., \& Morrison, K. (2007). Research methods in education (6th ed.). Routledge: New York.

Cropley, D., \& Cropley, A. (2010). Recognizing and fostering creativity in technological design education. International Journal of Technology and Design Education, 20(3), 345-358. http://dx.doi.org/10.1007/s10798-009-9089-5

Da Silva, N., \& Davis, A. (2011). Absorptive capacity at the individual level: Linking creativity to innovation in academia. The Review of Higher Education, 34(3), 355-379. https://doi.org/10.1353/rhe.2011.0007

DiPietro, W. R. (2009). Country innovativeness and the difficulty of doing business. Journal of Global Business Issues, 3(2), 69-75.

Edmondson, A. C. (2013). Teaming to innovate. San Francisco, CA: Jossey-Bass.

*(10) Edwards-Schachter, M., García-Granero, A., Sánchez-Barrioluengo, M., Quesada-Pineda, H., \& Amara, N. (2015). Disentangling competences: Interrelationships on creativity, innovation and entrepreneurship. Thinking Skills and Creativity, 16(0), 27-39. https://doi.org/10.1016/j.tsc.2014.11.006 
European Commission. (2012). Rethinking education: Investing in skills for better socio-economic outcomes. Retrieved from http://eur-lex.europa.eu/legal-content/EN/TXT/PDF/?uri=CELEX:52012DC0669\&from=FR . Accessed 13.03.16.

European Commission. (2013). Entrepreneurship 2020 action plan: Reigniting the entrepreneurial spirit in Europe. Retrieved from http://eur-lex.europa.eu/legal-content/EN/TXT/PDF/?uri=CELEX:52012DC0669\&from=FR . Accessed 13.03.16.

European Commission. (2017). Communication from the commission to the European parliament, the Council, the European economic and social committee and the Committee of the regions on a renewed EU agenda for higher education. Retrieved from https://ec.europa.eu/education/sites/education/files/he-com-2017-247_en.pdf Accessed 25.8.2017.

Farrell, M. P. (2001). Collaborative circles: Friendship dynamics and creative work. Chicago: University of Chicago Press.

Goswami, S., \& Chandra, B. (2013). Convergence dynamics of consumer innovativeness vis-á-vis technology acceptance propensity: An empirical study on adoption of mobile devices. IUP Journal of Marketing Management, 12(3), 63-87.

Greenhalgh, T. (1997). How to read a paper: Papers that summarise other papers (systematic reviews and meta-analyses). British Medical Journal, 315(7109), 672-675. https://doi.org/10.1136/bmj.315.7109.672

Greenhalgh, T., Robert, G., Macfarlane, F., Bate, P., \& Kyriakidou, O. (2004). Diffusion of innovations in service organisations: Systematic review and recommendations. Milbank Quarterly, 82(4), 581-629. https://doi.org/10.1111/j.0887-78X.2004.00325.x

*(11) Gundry, L. K., Ofstein, L. F., \& Kickul, J. R. (2014). Seeing around corners: How creativity skills in entrepreneurship education influence innovation in business. International Journal of Management Education, 12(3), 529-538. https://doi.org/10.1016/j.ijme.2014.03.002

Hasu, M., Honkaniemi, L., Saari, E., Mattelmäki, T., \& Koponen, L. (2014). Learning employee-driven innovating. Journal of Workplace Learning, 26(5), 310-330. https://doi.org/10.1108/JWL-10-2013-0079

Higgins, J. P. (Ed.). (2008). Cochrane handbook for systematic reviews of interventions (Vol. 5). Chichester: Wiley-Blackwell. https://doi.org/10.1002/9780470712184

Hippel, E. von (2005). Democratizing innovation. Cambridge, MA: MIT Press.

Høyrup, S., Bonnafous-Boucher, M., Hasse, C., Lotz, M., \& Moller, K. (2012). Employee-driven innovation: A new approach. Chippenham \& Eastbourne: CPI Antony Rowe. https://doi.org/10.1057/9781137014764

Iddris, F. (2016). Innovation capability: A systematic review and research agenda. Interdisciplinary Journal of Information. Knowledge, and Management, 11, 235-260.

*(12) Jack, C., Anderson, D., \& Connolly, N. (2014). Innovation and skills: Implications for the agri-food sector. Education \& Training, 56(4), 271-286. https://doi.org/10.1108/ET-11-2012-0122

*(13) Jaiswal, N. K., \& Dhar, R. L. (2015). Transformational leadership, innovation climate, creative self-efficacy and employee creativity: A multilevel study. International Journal of Hospitality Management, 51(October), 30-41. https://doi.org/10.1016/j.ijhm.2015.07.002

Jena, S., \& Sahoo, C. K. (2014). Improving managerial performance: A study on entrepreneurial and leadership competencies. Industrial and Commercial Training, 46(3), 43-149. https://doi.org/10.1108/ ICT-10-2013-0066

John-Steiner, V. (2000). Creative collaboration. New York: Oxford University Press.

*(14) Kasule, G. W., Wesselink, R., \& Mulder, M. (2014). Developing innovation competence profile for teaching staff in higher education in Uganda. Journal of Education, 2(2), 1-26.

*(15) Kasule, G. W., Wesselink, R., Noroozi, O., \& Mulder, M. (2015). The current status of teaching staff innovation competence in Ugandan universities: Perceptions of managers, teachers, and students. Journal of Higher Education Policy and Management, 37(3), 330-343. https://doi.org/10.1080/1360080X.2015.1034425

*(16) Keller, R. T. (2012). Predicting the performance and innovativeness of scientists and engineers. The Journal of Applied Psychology, 97(1), 225-233. https://doi.org/10.1037/a0025332 
Kesting, P., \& Ulhøi, J. P. (2010). Employee-driven innovation: Extending the license to foster innovation. Management Decision, 48(1), 65-84. https://doi.org/10.1108/00251741011014463

Kodama, M., \& Shibata, T. (2014). Strategy transformation through strategic innovation capability: A case study of Fanuc. $R \& D$ Management, 44(1), 75-103. https://doi.org/10.1111/radm.12041

Krippendorff, K. (2004). Content analysis: An introduction to its methodology (2nd ed.). California: Sage Publications.

Lim, B. T., Moriarty, H., \& Huthwaite, M. (2011). "Being-in-role": A teaching innovation to enhance empathic communication skills in medical students. Medical Teacher, 33(12), 663-669. https://doi.org/10.3109/0142159X.2011.611193

Lepistö, J., \& Lindfors, E. (2015). From gender-segregated subjects to multi-material craft: Craft student teachers' views on the future of the craft subject. Formakademisk, 8(3), 1-20. https://doi.org/10.7577/formakademisk.1313

*(17) Lindfors, E., \& Hilmola, A. (2015). Innovation learning in comprehensive education? International Journal of Technology and Design Education. https://doi.org/10.1007/s10798-015-9311-6

Manning, K. C., Bearden, W. O., \& Madden, T. J. (1995). Consumer innovativeness and the adoption process. Journal of Consumer Psychology, 4(4), 329-345. https://doi.org/10.1207/s15327663jcp0404_02

*(18) Mathisen, G. E, Martinsen, Ø., \& Einarsen, S. (2008). The relationship between creative personality composition, innovative team climate, and team innovativeness: An input-process-output perspective. Journal of Creative Behavior, 42(1), 13-31. https://doi.org/10.1002/j.2162-6057.2008.tb01078.x

McFall, R. M. (1982). A review and reformulation of the concept of social skills. Behavioral Assessment, 4(1), 1-33. https://doi.org/10.1007/BF01321377

McLellan, R., \& Nicholl, B. (2011). 'If I was going to design a chair, the last thing I would look at is a chair'. Product analysis and the causes of fixation in students' design work 11-16 years. International Journal of Technology and Design Education, 21(1), 71-92. https://doi.org/10.1007/s10798-009-9107-7

Mention, A. L. (2012). Intellectual capital, innovation and performance: A systematic review of the literature. Business and Economic Research, 2(1), 1-37. https://doi.org/10.5296/ber.v2i1.1937

Miettinen, R. (2013). Innovation, human capabilities, and democracy: Towards an enabling welfare state. Oxford: Oxford University Press. https://doi.org/10.1093/acprof:oso/9780199692613.001.0001

Mitchelmore, S., \& Rowley, J. (2010). Entrepreneurial competencies: A literature review and development agenda. International Journal of Entrepreneurial Behaviour Research, 16(2), 92-111. https://doi.org/10.1108/13552551011026995

Mitchelmore, S., \& Rowley, J. (2013). Entrepreneurial competencies of women entrepreneurs pursuing business growth. Journal of Small Business and Enterprise Development, 20(1), $125-142$. https://doi.org/10.1108/14626001311298448

Moher D., Liberati A., Tetzlaff J., Altman D. G., \& The PRISMA Group. (2009). Preferred reporting items for systematic reviews and meta-analyses: The PRISMA Statement. PLOS Medicine 6(6): e1000097. https://doi.org/10.1371/journal.pmed1000097

*(19) Montani, F., Odoardi, C., \& Battistelli, A. (2014). Individual and contextual determinants of innovative work behaviour: Proactive goal generation matters. Journal of Occupational and Organisational Psychology, 87(4), 645-670. https://doi.org/10.1111/joop.12066

Mulder, M. (2012). Competence-based education and training, The Journal of Agricultural Education and Extension, 18(3), 305-314. https://doi.org/10.1080/1389224X.2012.670048

Mulder, M., \& Gulikers, J. (2011) Workplace learning in East Africa: A case study. In M. Malloch, L. Cairns, K. Evans, \& B. O'Connor (Eds.), The SAGE handbook of workplace learning (pp. 307-318). London: SAGE. https://doi.org/10.4135/9781446200940.n22

*(20) Nielsen, J. A. (2015) Assessment of innovation competency: A thematic analysis of upper secondary school teachers' talk. Journal of Educational Research, 108(4), 318-330. http://dx.doi.org/10.1080/00220671.2014.886178

Nonaka, I., \& Takeuchi, H. (1995). The knowledge-creating company. New York: Oxford University Press. 
Nurmi, J. E. (1991). How do adolescent see their future? A review of the development of future orientation and planning. Developmental Review, 11, 1-59. https://doi.org/10.1016/0273-2297(91)90002-6

Nurmi, J. E. (2005). Thinking about and acting upon the future. In A. Strathman \& J. Joireman (Eds.), Understanding behavior in the context of time (pp. 31-57). New Jersey: Lawrence Erlbaum Associates Publishers.

OECD. (2004). Innovation in the knowledge economy: Implications for education and learning. Paris: OECD Publications. https://doi.org/10.1787/9789264105621-en

OECD. (2008). Innovating to learn, learning to innovate. Centre for Educational Research and Innovation, OECD 2008. https://doi.org/10.1787/annrep-2008-en

Peschl, M. F., Bottaro, G., Hartner-Tiefenthaler, M., \& Rötzer, K. (2014). Learning how to innovate as a socio-epistemological process of co-creation. Towards a constructivist teaching strategy for innovation. Constructivist Foundations, 9(3), 421-433.

Petticrew, M., \& Roberts, H. (2006). Systematic reviews in the social sciences: A practical guide. Malden, England: Blackwell. https://doi.org/10.1002/9780470754887

Rautkorpi, T., \& Hero, L.-M. (2017). Promoting students' reflections in organizational improvisation arrangement between higher education and workplaces. Nordic Journal of Vocational Education and Training, 7(1), 1-22. https://doi.org/10.3384/njvet.2242-458X.17711

Riggio, R. E. (1986). Assessment of basic social skills. Journal of Personality and Social Psychology, 51(3), 649-660. https://doi.org/10.1037/0022-3514.51.3.649

*(21) Rose-Anderssen, C., \& Allen, P. M. (2006). Diversity and learning for innovation: Dialogue for collaboration. Journal of Management Development, 27(3), 307-327. https://doi.org/10.1108/02621710810858623 ×

*(22) Santandreu-Mascarell, C., Canós-Darós, L., \& Pons-Morera, C. (2011). Competences and skills for future industrial Engineers defined in Spanish degrees. Journal of Industrial Engineering and Management, 4(1), 13-30. http://dx.doi.org/10.3926/jiem..v4n1.p13-30

*(23) Santandreu-Mascarell, C., Garzon, D., \& Knorr, H. (2013). Entrepreneurial and innovative competences, are they the same? Management Decision, 51(5), 1084-1095. https://doi.org/10.1108/MD-11-2012-0792

Sawyer, R. K. (2003). Group creativity: Music, theater, collaboration. Mahwah, NJ: Erlbaum.

Sawyer, R. K. (2006). Educating for innovation. Thinking Skills and Creativity, 1(1), 41-48. https://doi.org/10.1016/j.tsc.2005.08.001

Sawyer, R. K. (2012). Explaining creativity: The science of human innovation (2nd ed.). New York: Oxford University Press.

Sawyer, R. K. (2014). The future of learning: Grounding educational innovation in the learning sciences. In R. K. Sawyer (Ed.), The Cambridge handbook of the learning sciences (2nd ed.) (pp. 726-746). Cambridge: Cambridge University Press. https://doi.org/10.1017/CBO9781139519526.043

Schumpeter, J. (1942). Capitalism, socialism, and democracy. New York: Harper.

Seginer, R. (2009). Future orientation: Developmental and ecological perspectives. New York: Springer. https://doi.org/10.1007/b106810

Smith, A., Courvisanos, J., Tuck, J., \& McEachern, S. (2011). Building innovation capacity: The role of human capital formation in enterprises - a review of the literature. Adelaide, Australia: National Centre for Vocational Education Research (NCVER).

Spencer, L., \& Spencer, S. (1993). Competence at work: Models for superior performance. New York: John Wiley $\&$ Sons.

Standing, C., Jackson, D., Larsen, A.-C., Suseno, Y., Fulford, R., \& Gengatharen, D. (2016). Enhancing individual innovation in organisations: A review of the literature. International Journal of Innovation and Learning, 19(1), 44-62. https://doi.org/10.1504/IJIL.2016.073288

Sturing, L., Biemans, H. J. A., Mulder, M., \& De Bruijn, E. (2011). The nature of study programmes in vocational education: Evaluation of the model for comprehensive competence-based vocational education in the Netherlands. Vocations and Learning, 4(3), 191-210. https://doi.org/10.1007/s12186-011-9059-4 
Szerb, L. (2003). The changing role of entrepreneur and entrepreneurship in network organisations. In I. Lengyel (Ed.), Knowledge transfer, small and medium-sized enterprises, and regional development in Hungary, (pp. 81-95). Szeged: JATE Press.

Taatila, V. P. (2010). Learning entrepreneurship in higher education. Education \& Training, 52(1), 48-61. https://doi.org/10.1108/00400911011017672

Tether, B., Mina, A., Consoli, D., \& Gagliardi, D. (2005). A literature review on skills and innovation. How does successful innovation impact the demand for skills and how do skills drive innovation? University of Manchester, UK: ESRC Centre on Innovation and Competition.

Thurlings, M., \& Evers, A. T. (2015). Toward a model of explaining teachers' innovative behavior: A literature review. Review of Educational Research, 85(3), 430-471. https://doi.org/10.3102/0034654314557949

Timmermans, O., Van Linge, R., Van Petegem, P., Van Rompaey, B., \& Denekens, J. (2012). Team learning and innovation in nursing: A review of the literature. Nurse Education Today, 32(1), 65-70. https://doi.org/10.1016/j.nedt.2011.07.006

Toner, P. (2011). Workforce skills and innovation: An overview of major themes in the literature. OECD Education Working Paper, 55, Paris: OECD Publishing.

Treffinger, D., Young, G., Selby, E., \& Shepardson, C. (2002). Assessing creativity: A guide for educators. Storrs, CT: National Research Centre on the Gifted and Talented.

*(24) Tsai, M.-T, Chen, C.-C., \& Chin, C.-W. (2010). Knowledge workers' interpersonal skills and innovation performance: An empirical study of Taiwanese high-tech industrial workers. Social Behavior and Personality, 38(1), 115-126. https://doi.org/10.2224/sbp.2010.38.1.115

Veryzer, R. W., Jr. (1998). Discontinuous innovation and the new product development process. Journal of Product Innovation Management, 15, 304-321. https://doi.org/10.1016/S0737-6782(97)00105-7

*(25) Vila, L. E., Pérez, P. J., \& Coll-Serrano, V. (2014). Innovation at the workplace: Do professional competencies matter? Journal of Business Research, 67(5), 752-757. https://doi.org/10.1016/j.jbusres.2013.11.039

*(26) Vila, L. E., Pérez, P. J., \& Morillas, F. G. (2012). Higher education and the development of competencies for innovation in the workplace. Management Decision, 50(9), 1634-1648. https://doi.org/10.1108/00251741211266723

Wang, C. (2014). A longitudinal study of innovation competence and quality management on firm performance. Innovation: Management, Policy \& Practice, 16(3), 392-403. https://doi.org/10.5172/impp.2014.16.3.392

*(27) Wang, D., \& Shuai, C. (2013). Does intellectual capital matter? High-performance work systems and bilateral innovative capabilities. International Journal of Manpower, 34(8), 861-879. https://doi.org/10.1108/IJM-07-2013-0167

*(28) Waychal, P., Mohanty, R., \& Verma, A. (2011). Determinants of innovation as a competence: An empirical study. International Journal of Business Innovation and Research, 5(2), 192-211. https://doi.org/10.1504/IJBIR.2011.038781

Zang, J., Hong, H. Y., Scardamalia, M., Teo, C. L., \& Morley, E. A. (2011). Sustaining knowledge building at a principle-based innovation in an elementary school. The Journal of the Learning Sciences, 20(654), 262-307. https://doi.org/10.1080/10508406.2011.528317

Zhuang, L., Williamson, D., \& Carter, M. (1999). Innovate or liquidate: Are all organisations convinced? A two-phased study into the innovation process. Management Decisions, 37(1), 57-71. https://doi.org/10.1108/00251749910252030 
Appendix 1. Three-author bias assessment of the research data $(\mathrm{N}=28)$

\begin{tabular}{|c|c|c|c|c|}
\hline Study name, year & Context & Research design & $\begin{array}{l}\text { Study population } \\
(N=X) \text {, subjects }\end{array}$ & $\begin{array}{l}\text { Risk of bias (three } \\
\text { authors) }\end{array}$ \\
\hline $\begin{array}{l}\text { Arvanitis and Stucki, } \\
2012\end{array}$ & Organisational & $\begin{array}{l}\text { Quantitative, } \\
\text { three-phase } \\
\text { longitudinal survey }\end{array}$ & $\begin{array}{l}N=7112 \text { ( survey } 1 \\
N=1625 ; \text { survey } 2 \\
N=945 ; \text { survey } 3 \\
N=630), \text { firm founders } \\
\text { (start-ups, Switzerland) }\end{array}$ & $\begin{array}{l}\text { Moderate risk } 2 / 3 \text {, } \\
\text { medium risk } 1 / 3\end{array}$ \\
\hline Avvisati et al., 2013 & Educational & $\begin{array}{l}\text { Quantitative, two } \\
\text { surveys in } 20 \text { countries }\end{array}$ & $\begin{array}{l}N=50000, \text { tertiary } \\
\text { graduates } 5 \text { years after } \\
\text { graduation (14 European } \\
\text { countries and Japan) }\end{array}$ & No risk $3 / 3$ \\
\hline $\begin{array}{l}\text { Bjornali and Støren, } \\
2012\end{array}$ & $\begin{array}{l}\text { Educational } \\
\text { and } \\
\text { organisational }\end{array}$ & $\begin{array}{l}\text { Quantitative, surveys } \\
\text { in } 12 \text { countries }\end{array}$ & $\begin{array}{l}N=11777, \text { employed } \\
\text { graduates } 5 \text { years after } \\
\text { graduation (12 European } \\
\text { countries) }\end{array}$ & No risk $3 / 3$ \\
\hline Bruton, 2011 & Educational & $\begin{array}{l}\text { Quantitative, pre- and } \\
\text { post-course surveys } \\
\text { and tests }\end{array}$ & $\begin{array}{l}N=22, \text { students (higher } \\
\text { education) }\end{array}$ & $\begin{array}{l}\text { Moderate risk } 2 / 3 \text {, } \\
\text { medium risk } 1 / 3\end{array}$ \\
\hline Celik, 2013 & Educational & $\begin{array}{l}\text { Quantitative, three } \\
\text { surveys }\end{array}$ & $\begin{array}{l}N=252, \text { fourth-year } \\
\text { student teachers }\end{array}$ & $\begin{array}{l}\text { No risk } 2 / 3 \text {, moderate } \\
\text { risk } 1 / 3\end{array}$ \\
\hline $\begin{array}{l}\text { Cerinšek and Dolinšek, } \\
2009\end{array}$ & $\begin{array}{l}\text { Educational } \\
\text { and } \\
\text { organisational }\end{array}$ & $\begin{array}{l}\text { Qualitative, } \\
\text { triangulation: } \\
\text { literature review; } \\
\text { interviews and focus } \\
\text { groups }\end{array}$ & $\begin{array}{l}N=2 \text { (large organisations), } \\
\text { human resources } \\
\text { management specialists and } \\
\text { psychologists }\end{array}$ & $\begin{array}{l}\text { Medium risk } 1 / 3 \text {, high } \\
\text { risk } 2 / 3\end{array}$ \\
\hline Chatenier et al., 2010 & Organisational & $\begin{array}{l}\text { Qualitative, } \\
\text { triangulation: literature } \\
\text { review; explorative } \\
\text { interviews; and focus } \\
\text { groups }\end{array}$ & $\begin{array}{l}\text { Literature review }+N=20 \\
\text { (semi-structured } \\
\text { interviews) }+N=17 \text { (focus } \\
\text { groups), professionals } \\
\text { (Netherlands agri-food) }\end{array}$ & No risk $3 / 3$ \\
\hline $\begin{array}{l}\text { Chell and Athayde, } \\
2011\end{array}$ & Educational & $\begin{array}{l}\text { Qualitative, } \\
\text { triangulation: three } \\
\text { surveys; focus groups } \\
\text { and interviews; and a } \\
\text { multiple case study }\end{array}$ & $\begin{array}{l}\text { Surveys } N=2341 \text { (focus } \\
\text { groups and interviews) } \\
N=9 \text { (teachers) and } N=16 \\
\text { (students aged 14-18) }\end{array}$ & $\begin{array}{l}\text { No risk } 2 / 3 \text {, moderate } \\
\text { risk } 1 / 3\end{array}$ \\
\hline Cobo, 2013 & $\begin{array}{l}\text { Organisational } \\
\text { and } \\
\text { educational }\end{array}$ & $\begin{array}{l}\text { A comparative study of } \\
\text { job offer anouncements } \\
\text { for large companies } \\
\text { (document analysis) }\end{array}$ & $\begin{array}{l}N=36 \text { cases in } 6 \\
\text { companies }\end{array}$ & $\begin{array}{l}\text { Medium risk } 1 / 3 \text {, high } \\
\text { risk } 2 / 3\end{array}$ \\
\hline $\begin{array}{l}\text { Edwards-Schachter et. } \\
\text { al., } 2015\end{array}$ & Educational & $\begin{array}{l}\text { Quantitative, survey } \\
\text { study }\end{array}$ & $\begin{array}{l}N=196, \text { engineering } \\
\text { students (Spain and USA) }\end{array}$ & $\begin{array}{l}\text { Moderate risk } 2 / 3 \text {, } \\
\text { medium risk } 1 / 3\end{array}$ \\
\hline Gundry et al., 2014 & Educational & $\begin{array}{l}\text { Quantitative, survey } \\
\text { study }\end{array}$ & $N=137$, students (USA) & $\begin{array}{l}\text { Moderate risk } 1 / 3 \text {, } \\
\text { medium risk } 2 / 3\end{array}$ \\
\hline Jack et al., 2014 & Organisational & Quantitative, survey & $\begin{array}{l}N=30 \text { firms, (Northern } \\
\text { Ireland agri-food sector) }\end{array}$ & Moderate risk 3/3 \\
\hline Jaiswal and Dhar, 2015 & Organisational & Qantitative, survey & $\begin{array}{l}N=372, \text { employees and } \\
\text { their supervisors (hotels in } \\
\text { India) }\end{array}$ & $\begin{array}{l}\text { Moderate risk } 1 / 3 \text {, } \\
\text { medium risk } 2 / 3\end{array}$ \\
\hline
\end{tabular}


Kasule et al., $2015 \quad$ Educational Qantitative, survey

Kasule et al. 2014

Keller, 2012

Lindfors and Hilmola, Educational 2015

Mathisen et al., 2008

Montani et al., 2014

Nielsen, 2015

Rose-Anderssen and Allen, 2006

and
Educational

organisational

Mixed methods (review, survey, focus groups)

Organisational Quantitative, longitudinal multiple survey (10 years)

Quantitative, survey Analysis: Brim quartiles

Organisational Quantitative, survey, statistical analysis

Organisational Quantitative, two surveys (time lag of 6 months)

Educational Qualitative, multiple-case study

Organisational Mixed methods case study, action research (pilot project, two surveys and interviews)

Santandreu-Mascarellet Organisational Qualitative, document et al., 2011 analysis

Santandreu-Mascarellet Organisationa et al., 2013

Tsai et al. 2010

Organisational

Qualitative, mixed methods

Quantitative, survey, hierarchical multiple regression analysis

Vila et al. 2014

Organisational Quantitative, survey

\section{Vila et al., 2012}

Educational

Quantitative, survey

Wang and Shuai, 2013

Organisational Quantitative, survey

Waychal et al., 2011
$N=395$, higher education managers, teachers and students

$N=28$ (literature review)

$N=200$ (survey)

$N=11$ (focus groups),

teaching and other higher education staff

$N=644$, scientists and engineers

$N=661$, students aged

15-16

$N=147$ (29 teams), firm

employees (Scandinavian TV sector)

Phase 1: $N=210$ Phase 2: $N$ No risk 2/3, moderate $=107$, firm employees risk $1 / 3$

(Italy)

$N=28$, upper secondary teachers

2 x $N=25$, firm employees

$N=15$ universities (engineering), comparison of information given by universities (Spain) and the requirements of firms

$N=1163$ entrepreneurs

$N=27$ firm CEOs

$N=130, \mathrm{R} \& \mathrm{D}$ engineers

and managers in technological firms

(Taiwan)

$N=5474$, firm employees

(Spain) 5 years after

graduation

$N=5400$, graduates (Spain)

$N=164$ firms, Firm employees (China)

$N=441$, mid-level managers with more than 10 years of experience (IT sector, India)
No risk 2/3, medium risk $1 / 3$

Moderate risk 2/3, medium risk $1 / 3$ risk $1 / 3$, medium risk $1 / 3$

Moderate risk 2/3, medium risk $1 / 3$

Moderate risk 2/3, medium risk $1 / 3$
No risk $1 / 3$, moderate

Moderate risk 1/3, medium risk $2 / 3$, high risk $1 / 3$

Medium risk 1/3, high risk $2 / 3$

No risk $1 / 3$, moderate risk $2 / 3$

No risk 3/3,

No risk 3/3

No risk $1 / 3$, moderate risk $1 / 3$, medium risk $1 / 3$

No risk $3 / 3$ 